\title{
Anti-Hyperglycemic and Insulin Sensitizer Effects of Turmeric and Its Principle Constituent Curcumin
}

\author{
Zeinab Ghorbani ${ }^{1}$; Azita Hekmatdoost ${ }^{2}$; Parvin Mirmiran ${ }^{2,3, *}$ \\ ${ }_{1}^{1}$ Faculty of Nutrition and Food Technology, National Nutrition and Food Technology Research Institute, Shahid Beheshti University of Medical Science, Tehran, IR Iran \\ ${ }^{2}$ Department of Clinical Nutrition and Dietetics, Faculty of Nutrition Sciences and Food Technology, National Nutrition and Food Technology Research Institute, Shahid Beheshti \\ University of Medical Sciences, Tehran, IR Iran
${ }^{3}$ Nutrition and Endocrine Research Center, Obesity Research Center, Research Institute for Endocrine Sciences, Shahid Beheshti University of Medical Sciences, Tehran, IR Iran \\ ${ }^{*}$ Corresponding author: Parvin Mirmiran, Nutrition and Endocrine Research Center, Obesity Research Center, Research Institute for Endocrine Sciences, Shahid Beheshti University \\ of Medical Sciences, P.O. Box: 19395-4763, Tehran, IR Iran. Tel:+98-22357484, Fax: +98-2122416264, +98-2122402463, E-mail: mirmiran@endocrine.ac.ir
}

Received: February 21, 2014; Revised: June 15, 2014; Accepted: 28 July 2014

\begin{abstract}
Context: Turmeric is obtained from the plant Curcuma longa $\mathrm{L}$; its major constituent, curcumin, is a polyphenol with multiple effects which can modulate some signaling pathways.

Evidence Acquisition: Insulin resistance is a major risk factor for chronic diseases such as type 2 diabetes, atherosclerotic, metabolic syndrome and cardiovascular disease. In addition, Insulin resistance in peripheral tissue is one of the most important reasons of hyperglycemia which can cause global or systemic effects. The present study reviewed studies published in PubMed from 1998 to 2013 , indicating the role of curcumin in attenuation of many pathophysiological processes involved in development and progression of hyperglycemia and insulin resistance.

Results: Curcumin can reduce blood glucose level by reducing the hepatic glucose production, suppression of hyperglycemia-induced inflammatory state, stimulation of glucose uptake by up-regulation of GLUT4, GLUT2 and GLUT3 genes expressions, activation of AMP kinase, promoting the PPAR ligand-binding activity, stimulation of insulin secretion from pancreatic tissues, improvement in pancreatic cell function, and reduction of insulin resistance.

Conclusions:Curcumin has antihyperglycemic and insulin sensitizer effects. Thereby, more studies evaluating the effects of curcumin on hyperglycemic state and insulin resistance in related disorders such as diabetes are recommended.
\end{abstract}

Keywords: Turmeric; Curcumin; Curcuminoids; Curcuma longa; Hyperglycemia; Blood Glucose; Insulin Resistance; Hyperinsulinemia

\section{Context}

\subsection{Turmeric or Curcuma longa}

\subsubsection{Health Benefits}

Turmeric is obtained from the plant Curcuma longa L, which is a member of the ginger family. It is a rhizome consumed as a popular food ingredient in Iran as well as a key component of Indian, Chinese, Polynesian, Malaysian, and Thai curries, and western mustard preparing. The plant can be cultivated in tropical climate (1-3).

Turmeric has been used as a medical treatment in Asian countries for at least 2500 years (3). It has been used for centuries in Ayurvedic medicine and Unani systems of medicine as a therapy for inflammatory disorders, including hepatitis and arthritis, a blood purifier, a remedy for liver, stomach and dental problems, contraception, bactericide, germicide, beauty, deodorizing agent, disinfectant, a cure for leach and insect bites, cough, cold, sneeze, various types of skin diseases and related ail- ments such as Tinea versicolor, patches, itching, dermatitis, scabies, acne, psoriasis, rash, eruptions, and burn injuries. Based on these traditional applications, dietary supplements containing turmeric rhizome and extracts are also being used in western countries to prevent and treat arthritis (1,3-6)

\subsection{Curcumin}

Curcumin is a lipophilic polyphenol approximately insoluble in water, but is quite stable in the acidic $\mathrm{pH}$ of stomach (5). During the recent decades, polyphenol intakes have been getting greater attention, possibly because of their protective roles against various degenerative diseases such as cardiovascular diseases and cancer (7). Curcumin is a polyphenol with multiple effects which can modulate the biological activity of a number of signaling pathways. Chemical structure of curcumin is 1 , 7-bis [4-hydroxy-3-methoxyphenyl]-1, 6-heptadiene-3,5dione (Figures 1-3) (4, 6, 8). Chemical structure of curcumin as a component of turmeric or a single supplement plays a role in suppression of platelet aggregation,

Copyright (C) 2014, Research Institute For Endocrine Sciences and Iran Endocrine Society; Published by Kowsar. This is an open-access article distributed under the terms of the Creative Commons Attribution-NonCommercial 4.0 International License (http://creativecommons.org/licenses/by-nc/4.0/) which permits copy and redistribute the material just in noncommercial usages, provided the original work is properly cited. 
tumor genesis, metastasis, oxidative processes, inflammatory cytokine production, and myocardial infarction. Curcumin can modulate cystic fibrosis defects, lower cholesterol, suppress diabetes, improve wound healing, enhance multiple sclerosis, and block human immunodeficiency virus (HIV) replication. Moreover, reports also demonstrate the role of curcumin in protection against cataract formation, adriamycin-induced nephrotoxicity, drug or alcohol induced liver injury, and Inflammatory Bowel Disease (IBD) (1). Extensive reports from in vitro and in vivo studies have manifested the molecular basis for pharmaceutical applications of this polyphenol against numerous chronic diseases such as cancer, autoimmune diseases, neurological diseases, metabolic disorders, and pulmonary, liver and cardiovascular diseases (6). Molecular targets of curcumin are summerized in Figure 2 and details follow.

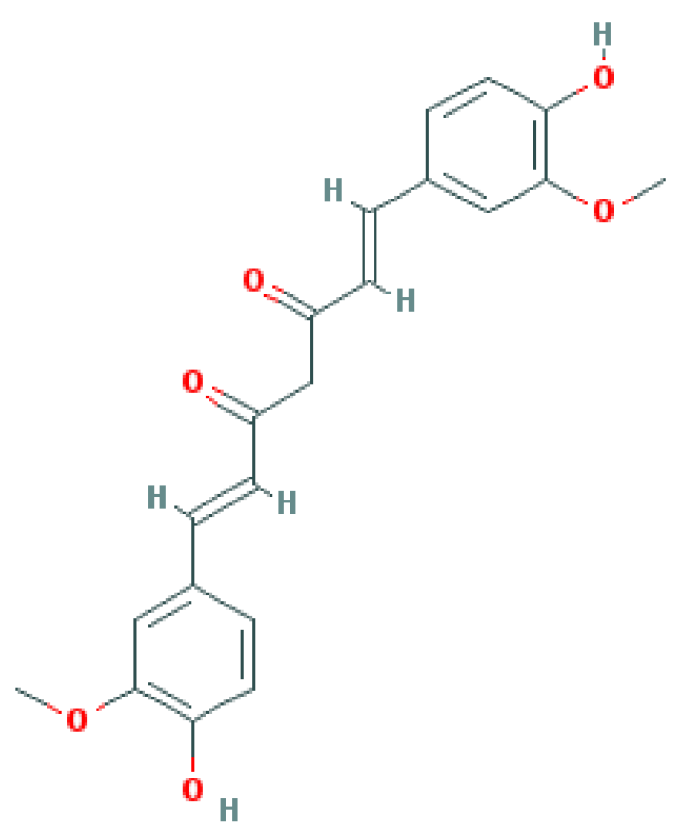

Figure 1. Chemical Structure of Curcumin

\subsubsection{Anti-Inflammatory and Antioxidant Effects of Cur- cumin}

Curcumin is constantly approved as an antioxidant and an anti-inflammatory agent. It seems that the hydroxyl and methoxy groups of curcumin are responsible for such effects (9). Curcumin performs these effects by modulating signaling pathways with many molecular targets (Figure 2) (10). Curcumin down-regulates signaling through the JAK/STAT pathway, which leads to negative regulation of proinflammatory interleukins (IL-1, $-2,-6,-8,-12$ ), and cytokines (tumor necrosis factor-alpha (TNF- $\alpha$ ), monocyte chemoattractant protein-1 (MCP-1)). Curcumin modulates the inflammatory response by down-regulating the activity of cyclooxygenase-2 (COX2), lipoxygenase, xanthine oxidase, and inducible nitric oxide synthase (iNOS) enzymes, resulting in inhibition of STAT3 phosphorylation and consequent STAT3 nuclear translocation (8-13) Curcumin inhibitions of COX-2 and iNOS are possibly contributed to suppression of the nuclear factor kappaB (NF-B) activation by this polyphenol. NF-B increases the expression of proinflammatory cytokines genes such as IL-1 and TNF- $\alpha$ and also stimulates the expression of inflammatory process enzymes including iNOS and COX-2 (9). TNF- $\alpha$ up-regulates the gene expression of various inflammatory cytokines which have causal association with hypertension, obesity, and high fasting glucose, decrease insulin sensitivity, and may lead to insulin resistance (IR), type 2 diabetes, and cardiovascular disease (14). Some studies have indicated that the beneficial anti-inflammatory effect of curcumin is mediated by up-regulation of peroxisome proliferator-activated receptor- $\gamma$ (PPAR- $\gamma$ ) activation (15).

Curcumin stimulates the expression of Nrf2 and HO1. Nrf2 is expressed in a wide range of tissues, many of which are sites of expression for phase 2 detoxification genes; It binds to the nuclear factor-erythroid derived 2 (NF-E2) binding sites, consisted of a subset of antioxidant response elements (ARE), which is a critical mechanism of protection against free radicals (9).

\subsection{Hyperglycemia and Hyperinsulinemia}

\subsubsection{Insulin Function and Insulin Resistance}

Insulin is a hormone with multiple effects. Binding of insulin to the $\alpha$-subunit of the insulin receptor molecule induces rapid auto-phosphorylation of the $\beta$-subunit, which lead to increase of its tyrosine kinase activity. Tyrosine phosphorylation of insulin receptor proteins induces the cytoplasmic binding activity of insulin receptor substrate-1 (IRS-1) to insulin receptor. IRS-1 plays a key role in transmitting signals from insulin receptors to intracellular PI3K/Akt and MAP kinase pathways, which eventually results in the second intracellular step of insulin action (16-18), protein-tyrosine phosphatase $1 \mathrm{~B}$ (PTP1B), a negative regulator of insulin signaling, which is elevated in obesity, targeting tyrosine-phosphorylated insulin receptor $\beta$ and IRS-1. Therefore, PTP1B inhibition causes elevated insulin sensitivity and glucose tolerance; thus, inhibition of PTP1B can be a new target in treatment of impaired glucose tolerance and insulin signaling in diabetic patients (16). Some of the substances possibly affecting or playing roles in insulin signaling are shown in Table 1.

IR is a condition in which defects in the action of insulin are such that normal levels of insulin do not operate as the signal for glucose uptake. Pancreas compensates for the decreased insulin response by increasing the insulin secretion; however, the result is hyperinsulinemia to maintain euglycemia. This process will continue until the reserve capacity is surpassed by metabolic demands and insulin secretion is no more sufficient; then, blood glucose concentration rises and glucose intolerance and type 2 diabetes develop (18-20).

Int J Endocrinol Metab. 2014;12(4):e18081 


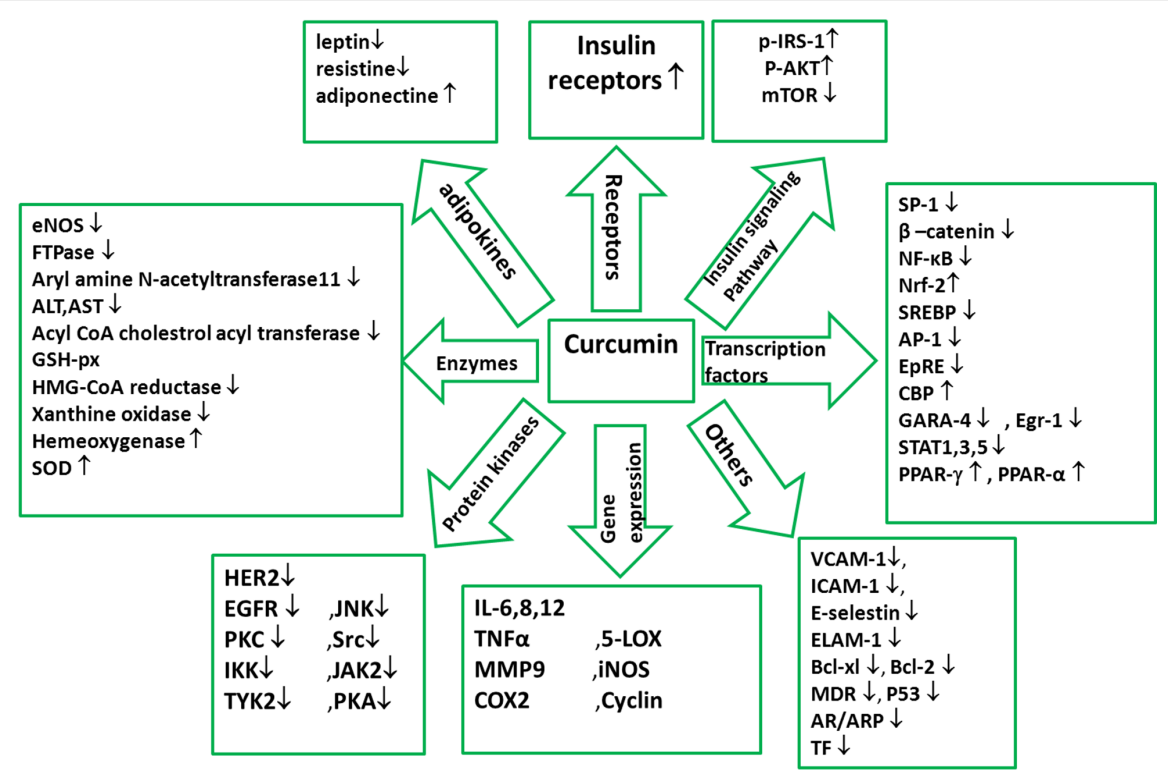

Figure 2. Molecular Targets of Curcumin

Adipocytes decrease glucose uptake in peripheral tissues by release of free fatty acids (FFAs). It seems that FFAs induce IR in muscle at the level of insulin-dependent glucose transport by impairing the insulin-signaling pathway $(17,18)$. On the other hand, when the serum FFAs concentration rises, signs of chronic inflammation are observed with the release of inflammatory cytokines including TNF- $\alpha$, IL- 6 , and IL-1 $\beta$, which have been implicated in pathogenesis of insulin resistance (17). Furthermore, increased oxidative stress and accumulation of lipid peroxidation metabolites in body, pancreatic beta cell dysfunction, mitochondrial dysfunction, and decreased FA $\beta$-oxidation are other factors which can lead to insulin resistance $(17,19)$.

Therefore, insulin resistance, even in the absence of obesity, is also a major risk factor for related chronic diseases such as type 2 diabetes, atherosclerotic and cardiovascular disease. Insulin resistance is a key component of metabolic syndrome, consisted of a series of risk factors such as abdominal obesity, hypertension, insulin resistance, and dyslipidemia (20)

\subsubsection{Hyperglycemia}

The process of glucose homeostasis maintains the plasma glucose levels within a narrow range, usually between 60 and $150 \mathrm{mg} / \mathrm{dL}(17,18)$. GLUT-4 is located on cell membranes of muscle cells and adipocytes. Insulin binds to its receptor and initiates a signaling cascade which leads to translocation of GLUT- 4 to plasma membrane, thus, permitting the influx of glucose; in the absence of insulin, GLUT-4 in cytosol is surrounded by membrane vesicles (18). Insulin resistance of peripheral tissue, discharge of glycogen storage, changed digestion and absorption of dietary carbohydrate, increased gluconeogenesis
Table 1. Some Substances With Possible Roles in Insulin Signaling $^{\mathrm{a}}(11,12,16,21)$

\begin{tabular}{lc}
\hline $\begin{array}{l}\text { Substance } \\
\text { Name }\end{array}$ & Role in Insulin Signaling \\
\hline GLUT & $\begin{array}{c}\text { Translocated to plasma membrane for glucose } \\
\text { influx }\end{array}$ \\
IL-6 & $\begin{array}{c}\text { Impairs/inhibits insulin signaling; suppresses } \\
\text { adipogenesis and secretion of adiponectin }\end{array}$ \\
NF-kB & $\begin{array}{c}\text { Influences gene transcription; inhibited by } \\
\text { adiponectin }\end{array}$
\end{tabular}

PPAR- $\gamma \quad$ Stimulates free fatty acid (FFA) catabolism; thiazolidinediones (TZDs) are PPAR- $\gamma$ agonists

TNF $\alpha \quad$ Main factor for stimulating the secretion of FFAs from adipose tissue into circulation; impairs insulin signaling

MCP-1 Impairs insulin-stimulated glucose uptake; promotes atherosclerosis

FFAs Adipocytes decrease glucose uptake in peripheral tissues by releasing free fatty acids

Akt key regulator of insulin action and glucose
uptake in mammals

IRS-1 Plays a key role in transmitting signals from insulin receptor to intracellular PI3K/Akt pathways and Ras/mitogen activated protein kinase, which eventually mediate various actions of insulin

PTP1B A negative regulator of insulin signaling which targets tyrosine-phosphorylated insulin receptor $\beta$ and IRS-1

mTOR Inhibits IRS-1 tyrosine phosphorylation

a GLUT, Glucose transporter; IL-6, Interleukin-6; NF-кB, Nuclear transcription factor $\kappa \mathrm{B}$; PPAR- $\gamma$, Peroxisome proliferator-activated receptor-gamma; TNF $\alpha$, Tumor necrosis factor alpha; MCP-1,Monocyte chemoattractant protein-1; FFAs, free fatty acids; Akt, protein kinase B; IRS-1, insulin receptor substrate-1; PTP1B, protein-tyrosine phosphatase $1 \mathrm{~B} ; \mathrm{mTOR}$, mammalian target of rapamycin. 
and over output hepatic glucose, and $\beta$-cell dysfunction are the most important reasons of hyperglycemia (22).

\subsubsection{Hyperglycemia-Induced Tissue Damage}

High flux of glucose across endothelial cell membranes is the initial point in the process of hyperglycemia-induced tissue damage. Increased glucose levels induce excess production of ROS, promote the protein kinase $\mathrm{C}$ (PKC) activity, and elevate the hexosamine pathway activation. Therefore, the generated oxidative stress can be responsible for the harmful effects of chronic hyperglycemia on pancreatic $\beta$-cell function. Additionally, pancreatic islets are chiefly composed of $\beta$ cells and have the lowest antioxidant capacity among all metabolic tissues. Generally, it seems that over-productions of ROS and PKC mediate hyperglycemia-induced insulin resistance (23, $24)$. Moreover, hyperglycemia causes global or systemic effects such as vascular inflammation and immune system impairment by stimulating inflammatory cytokines and cell adhesion molecules and by inhibiting leukocyte function (18). This review summarized what is currently known about the effects of turmeric and its components on plasma glucose and insulin levels. Recent literature suggested that turmeric and its major component, cur- cumin, have antihyperglycemic and insulin sensitizer effects. We therefore aimed to present the putative mechanisms linking curcumin to blood glucose and insulin resistance.

\section{Evidence Acquisition}

The present study reviewed studies published from 1998 to 2013, indicating that curcumin attenuates many of the pathophysiological processes involved in development and progression of hyperglycemia and insulin resistance. It was based on a PubMed and Science Direct literature search using the fallowing MeSH terminology and keywords: turmeric, curcumin, curcuminoids, Curcuma longa, hyperglycemia, blood glucose, insulin resistance, and hyperinsulinemia.

\section{Results}

\subsection{Studies Conducted on the Effects of Curcumin on Blood Glucose Levels and Insulin Resistance}

\subsubsection{In Vivo/in Vitro Experiments}

In vitro and in vivo studies are summarized in Table 2. \begin{tabular}{l}
\hline Table 2. Beneficial Effects of Supplementary Curcumin on Hyperglycemic Animal Models and High Glucose State Cell Culture \\
\hline In Vivo/in Vitro Dose, Duration Results In the End of the Study in Treat-
\end{tabular}

\begin{tabular}{llc} 
experiment & & ment Group \\
\hline STZ induced & $60 \mathrm{mg} / \mathrm{kg}$ Cur- & $\uparrow$ Gene expression of: acetylcholine ester- \\
$\begin{array}{l}\text { Diabetic Wistar } \\
\text { rats } \mathbf{5 5} \mathbf{~ m g / k g )}\end{array}$ & cumin 14 days & $\begin{array}{c}\text { ase, Glut3 Muscarinic M1, M3, } \alpha 7 \text { nicotinic } \\
\text { acetylcholine and insulin receptors }\end{array}$
\end{tabular}
rats $(55 \mathrm{mg} / \mathrm{kg})$

Overall Conclusion
Curcumin plays an important role in
regulating the activity of cholinergic and
insulin receptors and mechanism of glu-
cose transportation through Glut3, which
lead to normalizing the diabetes-mediated
cerebellar disorders. Thus, Curcumin has a
significant role in a therapeutic applica-
tion for the prevention or progression of
diabetic complications in the cerebellum.

\begin{tabular}{|c|c|c|c|c|c|}
\hline $\begin{array}{l}\text { high-fat } \\
\text { diet }+30 \mathrm{mg} / \mathrm{kg} \\
\text { STZ induced } \\
\text { Diabetic rats } \\
\text { (in vivo study) }\end{array}$ & $\begin{array}{l}3 \text { groups } 50,150, \\
\text { or } 250 \mathrm{mg} / \mathrm{kg} \\
\text { Curcumin. } 7 \text { wk }\end{array}$ & $\begin{array}{l}\text { plasma lipids and glucose } \downarrow \text {,glucose } \\
\text { uptake } \uparrow \text {, phosphorylated acetyl COA } \\
\text { carboxylase in L6 myotubes } \uparrow \text {, phos- } \\
\text { phorylated AMPK } \uparrow \text {, carnitine palmitoyl } \\
\text { transferase } 1 \uparrow \text {, pyruvate dehydrogenase } 4 \\
\downarrow \text {, phosphorylated glycogen synthase (GS) } \\
\downarrow \text {, glycogen synthesis in skeletal muscle } \uparrow \text {, } \\
\text { in both in vivo and in vitro studies. }\end{array}$ & $\begin{array}{l}\text { Curcumin enhances muscular insulin } \\
\text { resistance by promoting oxidation of fatty } \\
\text { acid and glucose, which is, at least in part, } \\
\text { mediated through LKB1-AMPK pathway. }\end{array}$ & $\begin{array}{l}\mathrm{Na}, \mathrm{LX} \text { and col- } \\
\text { legues/2011 }\end{array}$ & (26) \\
\hline $\begin{array}{l}\text { L6 myotubes } \\
\text { (in vitro experi- } \\
\text { ment) }\end{array}$ & $\begin{array}{l}\text { Curcumin at } \\
5,10,20, \text { or } 40 \\
\mathrm{~mol} / \mathrm{L}\end{array}$ & & & & \\
\hline $\begin{array}{l}\text { high fat diet } \\
\text { induced Dia- } \\
\text { betic Sprague } \\
\text { Dawley rats }\end{array}$ & $\begin{array}{l}\text { Curcumin ( } 80 \\
\mathrm{mg} / \mathrm{kg}) 15 \text { days }\end{array}$ & $\begin{array}{c}\text { hyperglycemia } \downarrow \text {, Improve glucose toler- } \\
\text { ance, Improve lipid profile, Fasting insulin } \\
\uparrow, \text { Insulin sensivity } \uparrow\end{array}$ & $\begin{array}{l}\text { Curcumin exhibited an anti-hyperglycemic } \\
\text { effect and improved insulin sensitivity }\end{array}$ & $\begin{array}{l}\text { El-Moselhy,MA } \\
\text { and colleg- } \\
\text { ues/2011 }\end{array}$ & (27) \\
\hline $\begin{array}{l}\text { Alloxan in- } \\
\text { duced diabetic } \\
\text { rats }\end{array}$ & $\begin{array}{l}\text { Turmeric } 1 \mathrm{~g} / \mathrm{kg} \\
\text { and Curcumin } \\
0.08 \mathrm{~g} / \mathrm{kg} 21 \text { days }\end{array}$ & $\begin{array}{l}\text { blood sugar } \downarrow \text {, Hb and glycosylated hemo- } \\
\text { globin levels } \downarrow \text {, diabetic oxidative stress } \downarrow\end{array}$ & $\begin{array}{c}\text { Curcumin was more effective in attenuat- } \\
\text { ing diabetes mellitus related changes than } \\
\text { turmeric }\end{array}$ & $\begin{array}{l}\text { Arun,N and col- } \\
\text { leagues /2002 }\end{array}$ & (28) \\
\hline $\begin{array}{l}\text { Wild-type and } \\
\text { ob/ob C57BL/6J } \\
\text { mice }\end{array}$ & $\begin{array}{l}\text { Dietary Cur- } \\
\text { cumin (3\%)10 } \\
\text { wks. }\end{array}$ & $\begin{array}{c}\text { HbA1c levels } \downarrow \text {, improves glucose tolerance } \\
\text { blood glucose levels } \downarrow \text {, adipose, hepatic, } \\
\text { and systemic inflammation } \downarrow \text {, Serum } \\
\text { adiponectin levels } \uparrow \text {, serum levels of liver } \\
\text { and adipocytes MCP- } \downarrow \downarrow\end{array}$ & $\begin{array}{l}\text { Curcumin in high oral doses safely treat dia- } \\
\text { betes in several mouse models of obesity- } \\
\text { associated diabetes. Curcumin also greatly } \\
\text { improved inflammation at the cellular and } \\
\text { biochemical level in white adipose tissue of } \\
\text { obese mice. }\end{array}$ & $\begin{array}{l}\text { Weisberg,SP } \\
\text { and colleagues } \\
\text { /2008 }\end{array}$ & (29) \\
\hline $\begin{array}{l}\text { C57BL/ KsJ-ob/ } \\
\text { obmice }\end{array}$ & $\begin{array}{l}\text { Curcumin } \\
(0.02 \%, w t / w t) \\
\quad 6 \text { wks }\end{array}$ & $\begin{array}{c}\text { blood glucose } \downarrow \text {, HbA1c levels } \downarrow \text {, improved } \\
\text { HOMA-IR and glucose tolerance, plasma in- } \\
\text { sulin } \uparrow \text {, plasma free fatty acid, cholesterol, } \\
\text { and triglyceride concentrations hepatic } \\
\text { glycogen } \downarrow \text {, skeletal muscle lipoprotein } \\
\text { lipase } \uparrow, \text { lipid peroxidation. } \downarrow\end{array}$ & $\begin{array}{l}\text { It seems that Curcumin is a potential } \\
\text { glucose-lowering agent and antioxidant in } \\
\text { type } 2 \text { diabetic ob/obmice, but had no effect } \\
\text { in non-diabetic db/+ mice. }\end{array}$ & $\begin{array}{l}\text { Seo,KI and col- } \\
\text { leagues / } 2008\end{array}$ & (30) \\
\hline
\end{tabular}


Ghorbani Z et al.

\begin{tabular}{|c|c|c|c|c|c|}
\hline $\begin{array}{l}\text { type } 2 \text { diabetic } \\
\text { KK-Ay mice }\end{array}$ & $\begin{array}{l}\text { Turmeric Et-OH } \\
\text { Extract } 0.2 \text { or } 1.0 \\
\text { g/100 g diet } 4 \\
\text { Weeks }\end{array}$ & blood glucose level $\downarrow$ & $\begin{array}{l}\text { Turmeric Et-OH extract has PPAR- } \gamma \text { ligand- } \\
\text { binding activity which probably leads to } \\
\text { Adipocyte that finally result in the suppres- } \\
\text { sion of an increase in blood glucose levels } \\
\text { in type } 2 \text { diabetic KK-Ay mice }\end{array}$ & $\begin{array}{l}\text { Kuroda,M and } \\
\text { colleagues /2005 }\end{array}$ & $(31)$ \\
\hline $\begin{array}{l}\text { In Vitro Experi- } \\
\text { ments }\end{array}$ & $\begin{array}{l}\text { human pre- } \\
\text { adipocytes were } \\
\text { cultured with } \\
\text { the Turmeric } \\
\text { Et-OH Extract } \\
2.0,5.0,10 \text {, and } \\
20 \mathrm{~g} / \mathrm{ml}\end{array}$ & Stimulated adipocyte differentiation & & & \\
\hline $\begin{array}{l}\text { STZ induced } \\
\text { Diabetic rats }\end{array}$ & $\begin{array}{l}60 \mathrm{mg} / \mathrm{kg} \text { oral } \\
\text { Curcumin } 28 \\
\text { days }\end{array}$ & $\begin{array}{c}\text { The expression of both TNF- } \alpha \text { and TNF- } \alpha \\
\text { receptor } 1 \downarrow \text {, Hyperglycemia } \downarrow \text {, body } \\
\text { weight improved }\end{array}$ & $\begin{array}{l}\text { Curcumin seems to relieve diabetic hyperal- } \\
\text { gesia, probably through an inhibitory effect } \\
\text { on TNF- } \alpha \text { and TNF- } \alpha \text { receptor } 1 \text {. }\end{array}$ & $\begin{array}{l}\text { Li,Y and col- } \\
\text { leagues / } 2013\end{array}$ & $(32)$ \\
\hline $\begin{array}{l}\text { type } 2 \text { diabetic } \\
\text { KK-Ay mice }\end{array}$ & $\begin{array}{c}\text { turmeric } \\
\text { extracts:, } 0.1 \text { or } \\
0.5 \text { g of hexane } \\
\text { extraction/100 } \\
\text { g of diet, } 0.1 \text { or } \\
0.5 \text { g of ethanol, } \\
\text { extraction from } \\
\text { hexane-extrac- } \\
\text { tion residue/100 } \\
\text { g of diet } 0.2 \text { or } \\
1.0 \text { g of ethanol } \\
\text { extraction/100 g } \\
\text { of diet } 4 \text { weeks }\end{array}$ & $\begin{array}{c}\text { E-ext stimulated human adipocyte differ- } \\
\text { entiation turmeric extracts and Curcumin } \\
\text { had human peroxisome proliferator-acti- } \\
\text { vated receptor- } \gamma \text { (PPAR- } \gamma \text { ) ligand-binding } \\
\text { activity }\end{array}$ & $\begin{array}{l}\text { Both Curcuminoids and sesquiterpenoids } \\
\text { in turmeric exhibit hypoglycemic effects via } \\
\text { PPAR- } \gamma \text { activation as one of the mecha- } \\
\text { nisms, and suggest that E-ext including } \\
\text { Curcuminoids and sesquiterpenoids has } \\
\text { the additive or synergistic effects of both } \\
\text { components. }\end{array}$ & $\begin{array}{l}\text { Nishiyama,T } \\
\text { and colleagues } \\
\text { |2005 }\end{array}$ & (33) \\
\hline $\begin{array}{l}\text { Cell culture of } \\
\text { Pancreas and } \\
\text { muscle tissues } \\
\text { of adult mice }\end{array}$ & $\begin{array}{l}\text { aqueous extract } \\
\text { of turmeric }(100 \\
\text { g of ground } \\
\text { turmeric in } 1 \mathrm{~L} \text { of } \\
\text { water) various } \\
\text { dose }\end{array}$ & $\begin{array}{l}\text { insulin secretion from mouse pancreatic } \\
\text { tissues } \uparrow \text {, glucose uptake } \uparrow\end{array}$ & $\begin{array}{c}\text { Water soluble constituents of turmeric } \\
\text { exhibit insulin releasing and stimulat- } \\
\text { ing actions within in vitro tissue culture } \\
\text { conditions }\end{array}$ & $\begin{array}{l}\text { Mohankumar,S } \\
\text { and colleagues } \\
\text { /2010 }\end{array}$ & $(34)$ \\
\hline $\begin{array}{l}\text { Skeletal mus- } \\
\text { cle isolated } \\
\text { from Wistar } \\
\text { rats. }\end{array}$ & $\begin{array}{l}0.1-1 \text { m Curcum- } \\
\text { in on cultured } \\
\text { C2C12 cells }\end{array}$ & $\begin{array}{c}\text { glucose uptake into skeletal muscle } \\
\text { isolated } \uparrow \text {, the membrane protein level of } \\
\text { GLUT4 } \uparrow\end{array}$ & $\begin{array}{l}\text { Curcumin can activate muscarinic M-1 } \\
\text { cholinoceptor (M1-mAChR) at concentra- } \\
\text { tions lower than to scavenge free radicals } \\
\text { for increase of glucose uptake into skeletal } \\
\text { muscle through PLC-PI3-kinase pathway }\end{array}$ & $\begin{array}{l}\text { Cheng,TC and } \\
\text { colleagues /2009 }\end{array}$ & $(35)$ \\
\hline $\begin{array}{l}\text { In vivo: STZ in- } \\
\text { duced Diabetic } \\
\text { Sprague-Daw- } \\
\text { ley rats }\end{array}$ & $\begin{array}{l}\text { synthetic } \\
\text { analogues of } \\
\text { Curcumin )C66) } \\
(0.2,1.0 \text { or } 5.0 \\
\mathrm{mg} \cdot \mathrm{kg}-1), 6 \text { wks. }\end{array}$ & $\begin{array}{l}\text { TNF-a levels and renal inflammatory gene } \\
\text { expression } \downarrow \text { improved histological abnor- } \\
\text { malities and fibrosis of diabetic kidney }\end{array}$ & $\begin{array}{l}\text { This novel compound is a potential anti-in- } \\
\text { flammatory agent and might be beneficial } \\
\text { for the prevention of diabetic nephropathy; } \\
\text { but did not affect the hyperglycemia in } \\
\text { these diabetic rats. }\end{array}$ & $\begin{array}{l}\text { Pan,Y and col- } \\
\text { leagues / } 2012\end{array}$ & $(36)$ \\
\hline $\begin{array}{l}\text { In vitro :Prima- } \\
\text { ry peritoneal } \\
\text { macrophages } \\
\text { (MPM), pre- } \\
\text { pared from } \\
\text { C57BL/6 mice }\end{array}$ & $\begin{array}{l}\text { Treated with HG } \\
\text { (high glucose) in } \\
\text { the presence or } \\
\text { absence of C66. }\end{array}$ & $\begin{array}{l}\text { Inhibited HG-stimulated production of } \\
\text { TNF- } \alpha \text {, NO, IL-1 } \beta \text {, IL-6, IL-12, COX-2 and iNOS } \\
\text { mRNA transcription, and the activation of } \\
\text { JNK/NF-kB signalling }\end{array}$ & & & \\
\hline $\begin{array}{l}\text { Male Golden- } \\
\text { Syrian ham- } \\
\text { sters }\end{array}$ & $\begin{array}{l}\text { Curcumin } \\
\text { (0.05-g/100-g } \\
\text { diet) on a high- } \\
\text { fat diet } 10 \text { weeks. }\end{array}$ & $\begin{array}{c}\text { levels of free fatty acid, total cholesterol, } \\
\text { triglyceride } \downarrow \text {, leptin } \downarrow \text {, HOMA-IR } \downarrow \text {, HDL-C } \\
\uparrow \text {, apolipoprotein (apo)A-I } \uparrow \text {, paraox- } \\
\text { onase activity in plasma } \uparrow \text {, fatty acid } \\
\beta \text {-oxidation activity } \uparrow \text {, fatty acid synthase } \\
\downarrow, 3 \text {-hydroxy-3-methylglutaryl coenzyme A } \\
\text { reductase } \downarrow \text {, acyl coenzyme A:cholesterol } \\
\text { acyltransferase } \downarrow \text {, lipid peroxide levels in } \\
\text { the erythrocyte and liver } \downarrow\end{array}$ & $\begin{array}{l}\text { Curcumin showes an obvious hypo- } \\
\text { lipidemic effect by increasing plasma } \\
\text { paraoxonase activity, ratios of high-density } \\
\text { lipoprotein cholesterol to total cholesterol } \\
\text { and of apo A-I to apo B, and hepatic fatty } \\
\text { acid oxidation activity with simultaneous } \\
\text { inhibition of hepatic fatty acid and choles- } \\
\text { terol biosynthesis in high-fat-fed hamsters. }\end{array}$ & $\begin{array}{l}\text { Jang,EM and col- } \\
\text { leagues / } 2008\end{array}$ & (37) \\
\hline $\begin{array}{l}\text { low dose of STZ } \\
+ \text { high energy } \\
\text { intake induced } \\
\text { diabetic wistar } \\
\text { rats }\end{array}$ & $\begin{array}{l}\text { Curcumin } 100 \\
\text { or } 200 \mathrm{mg} / \mathrm{kg} / 16 \\
\text { weeks }\end{array}$ & $\begin{array}{c}\text { myocardial dysfunction } \downarrow \text {, cardiac fibrosis } \\
\downarrow \text {, AGEs accumulation } \downarrow \text {,oxidative stress } \\
\downarrow \text {,inflammation } \downarrow \text {,apoptosis } \downarrow \text {, phosphor- } \\
\text { ylation of Akt and GSK-3b } \uparrow \text { Activation Akt/ } \\
\text { GSK-3b Signaling Pathway } \uparrow \text { blood glucose } \\
\text { levels } \downarrow \text {, TG } \downarrow\end{array}$ & $\begin{array}{l}\text { Curcumin may have great therapeutic } \\
\text { effect in the treatment of DCM, and perhaps } \\
\text { other cardiovascular disorders, by enhanc- } \\
\text { ing fibrosis, oxidative stress, inflammation } \\
\text { and cell death }\end{array}$ & $\begin{array}{l}\text { Yu,W and col- } \\
\text { leagues /2012 }\end{array}$ & $(38)$ \\
\hline $\begin{array}{l}\text { STZ }(65 \mathrm{mg} / \\
\mathrm{kg}) \text { induced } \\
\text { Diabetic rats }\end{array}$ & $\begin{array}{l}\text { Curcumin }(15 \\
\text { and } 30 \mathrm{mg} / \mathrm{kg}) 2 \\
\text { weeks }\end{array}$ & renal dysfunction $\downarrow$, oxidative stress $\downarrow$ & $\begin{array}{l}\text { Perhaps anti-oxidative mechanism being } \\
\text { responsible for the nephroprotective effect } \\
\text { of Curcumin. }\end{array}$ & $\begin{array}{l}\text { Sharma,S and } \\
\text { colleagues /2006 }\end{array}$ & (39) \\
\hline $\begin{array}{l}\text { C57BL6 mice } \\
\text { (5-6 weeks old) }\end{array}$ & $\begin{array}{l}24 \text { weeks either } \\
\text { a high-fat diet } \\
\text { (45\% fat) or a } \\
\text { low-fat diet (10\% } \\
\text { fat) together } \\
\text { with CNB-001 } \\
(40 \mathrm{mg} / \mathrm{kg} / \mathrm{d})\end{array}$ & $\begin{array}{l}\text { a novel neuroprotective curcuminoid } \\
\text { CNB-001: body weight gain } \downarrow \text {, serum } \\
\text { triglycerides } \downarrow \text {, IL- } 6 \downarrow \text {, Improved insulin } \\
\text { signaling:p-Akt (phosphoprotein kinase } \\
\text { B) } \uparrow, \text { p-IR (phosphoinsulin receptor) } \beta \uparrow \text {, } \\
\text { endoplasmic reticulum (ER) stress } \downarrow \text {, pro- } \\
\text { teintyrosine phosphatase1B (PTP1B) } \downarrow\end{array}$ & $\begin{array}{l}\text { CNB-001 alleviates obesity-induced glucose } \\
\text { intolerance and represents a potential } \\
\text { candidate for further development as an } \\
\text { anti-diabetic agent }\end{array}$ & $\begin{array}{l}\text { Panzhinskiy E } \\
\text { and colleagues } \\
\qquad / 2014\end{array}$ & (16) \\
\hline
\end{tabular}

\footnotetext{
a STZ, Streptozotocin; HG, high glucose; p-Akt, phosphoprotein kinase B ; p-IR, phosphoinsulin receptor $\beta$; ER, endoplasmic reticulum; PTP1B, proteintyrosine phosphatase1B; TG,Triglyceride.
} 
Elmoselhy et al. showed that prophylactic oral administration of curcumin $(80 \mathrm{mg} / \mathrm{kg}$ ) was comparable to rosiglitazone $(1 \mathrm{mg} / \mathrm{kg})$, which may indicate that they mostly act similarly (27).

Six-week administration of curcumin $(0.02 \%$, wt $/ w t)$ in ob/ob mice could increase the hepatic glucokinase activity and decrease glucose-6-phosphatase and phosphoenolpyruvate carboxykinase activities significantly. In ob/ob mice, curcumin significantly lowered the hepatic activities of fatty acid synthase, -oxidation, 3-hydroxy3-methylglutaryl coenzyme reductase, and acyl-CoA: cholesterol acyltransferase. Curcumin significantly lowered plasma free fatty acids, cholesterol, and triglyceride concentrations and increased the hepatic glycogen and skeletal muscle lipoprotein lipase in ob/ob mice. Curcumin normalized erythrocyte and hepatic antioxidant enzyme activities (superoxide dismutase, catalase, glutathione peroxidase) in ob/ob mice which resulted in a significant reduction in lipid peroxidation (30). In an experimental model of streptozicine (STZP)-induced diabetes, oral administration of curcumin at a dose of $100 \mathrm{mg} / \mathrm{kg} /$ day for 8 weeks, significantly corrected all the abnormalities induced by STZ injection and hyperglycemia, such as renal dysfunction, reduced creatinine clearance, increased blood glucose, blood urea nitrogen and proteinuria, and significant reduction in the body weight. Curcumin treatment significantly decreased macrophage infiltration in kidneys of diabetic rats, inhibited the expression of proinflammatory cytokines such as TNF- $\alpha$ and IL-1, and degradation of I $\mathrm{B} \alpha$. Additionally, it significantly decreased ICAM-1, MCP-1 and TGF-1 protein expressions. Moreover, at nuclear level, curcumin inhibited the NF-B activity (40).

Fujiwara et al. showed that after 120 minutes of exposure to $25 \mathrm{mM}$ curcumin, hepatic gluconeogenesis and glycogenolysis were inhibited significantly. Curcumin $(25 \mathrm{mM})$ showed an additive inhibitory effect with insulin on both hepatic gluconeogenesis and glycogenolysis, indicating that it inhibits hepatic glucose production in an insulin-independent manner. After 120 minutes of exposure to $25 \mathrm{mM}$ curcumin, hepatic glucose-6-phosphatase (G6Pase) activity and phosphoenolpyruvate carboxykinase (PEPCK) activity were both inhibited by $30 \%$. After 120 minutes of exposure to $25 \mathrm{mM}$ curcumin, phosphorylation of AMP kinase a-Thr172 increased. They concluded that the antidiabetic effects of curcumin might be partly due to a reduction in hepatic glucose production caused by activation of AMP kinase and inhibition of G6Pase activity and PEPCK activity (41).

Pretreatment of pancreatic islets from C57/BL6J mice with curcumin $(10 \mathrm{mM})$ protected the islets from cytokine-induced islet death by scavenging ROS and normalized the cytokine production induced by NF-B translocation through inhibiting phosphorylation of inhibitor of kappa B alpha (I B $\alpha$ ). In addition, curcumin prevented STZ-induced diabetes, as manifested by sustained normoglycemia, had normal glucose clearance performance, and maintained pancreatic GLUT2 levels. Proinflammatory cytokine concentrations in serum and pancreas rose in
STZ-treated animals, but not in animals pretreated with curcumin before STZ injection (42).

\subsubsection{Curcumin, Cell Function and Insulin}

Curcumin activated the volume-regulated anion channels in cells. This effect was accompanied by depolarization of the cell membrane potential, generation of electrical activity, and enhanced insulin release. Curcumin also decreased the cell volume, presumably reflecting loss of $\mathrm{Cl}$ (and hence water) as a result of anion channel activation (43). In a recent study, administration of a new neuroprotective curcuminoid, CNB-001, improved intracellular insulin signaling, which was revealed by increased level of phosphoprotein kinase B (p-Akt), phosphor-insulin receptor (p-IR) $\beta$, as well as decreased level of endoplasmic reticulum (ER) stress, protein-tyrosine phosphatase $1 \mathrm{~B}$ (PTP1B), and glucose uptake in gastrocnemius muscle of HFD fed mice (16).

\subsubsection{The Curcumin Reduction Effects on Hyperglyce- mia-Induced Circulating ICAM-1, VCAM-1}

Endothelial cells release multiple inflammatory mediators and express various adhesion molecules such as intercellular adhesion molecule- 1 and vascular cell adhesion molecule-1 (ICAM-1, VCAM-1). An acute increase of plasma glucose may lead to an oxidative stress, resulting in increased cellular expression of ICAM-1 (44). In another study, hyperglycemia triggered an inflammatory response in the retina of normolipidemic mice and upregulated VCAM-1 in retinal vessels (45). Curcumin inhibits inflammation by blocking the adhesion of monocytes to endothelial cells. by inhibiting the activation of cell adhesion molecules ICAM-1 and VCAM-1 $(11,40)$.

\subsection{Human Clinical Trials of Curcumin}

Human clinical trials evaluating the effects of curcumin supplementation on blood glucose and insulin resistance are summarized in Table 3.

\subsection{Schematic Roles of Curcumin in Reduction} of Blood Glucose Level and Serum FFAs, Improvement of Inflammatory State and Decreasing Insulin Resistance

\subsubsection{Reduction of Blood Glucose Level by Curcumin}

AMPK pathway mediates the regulatory effect of curcumin on lipid and glucose oxidation and utilization, inhibits hepatic gluconeogenesis and glycogenolysis:

Inhibits hepatic G6Pase and phosphoenolpyruvate carboxykinase (PEPCK) activity. Increases phosphorylation of AMP kinase (which leads to phosphorylation of GEF (GLUT4 enhance factor)). Inhibits PDK4 expression. Decreases glycogen synthesis. Reduces hepatic glucose production.Increases PPAR ligand-binding activity. 


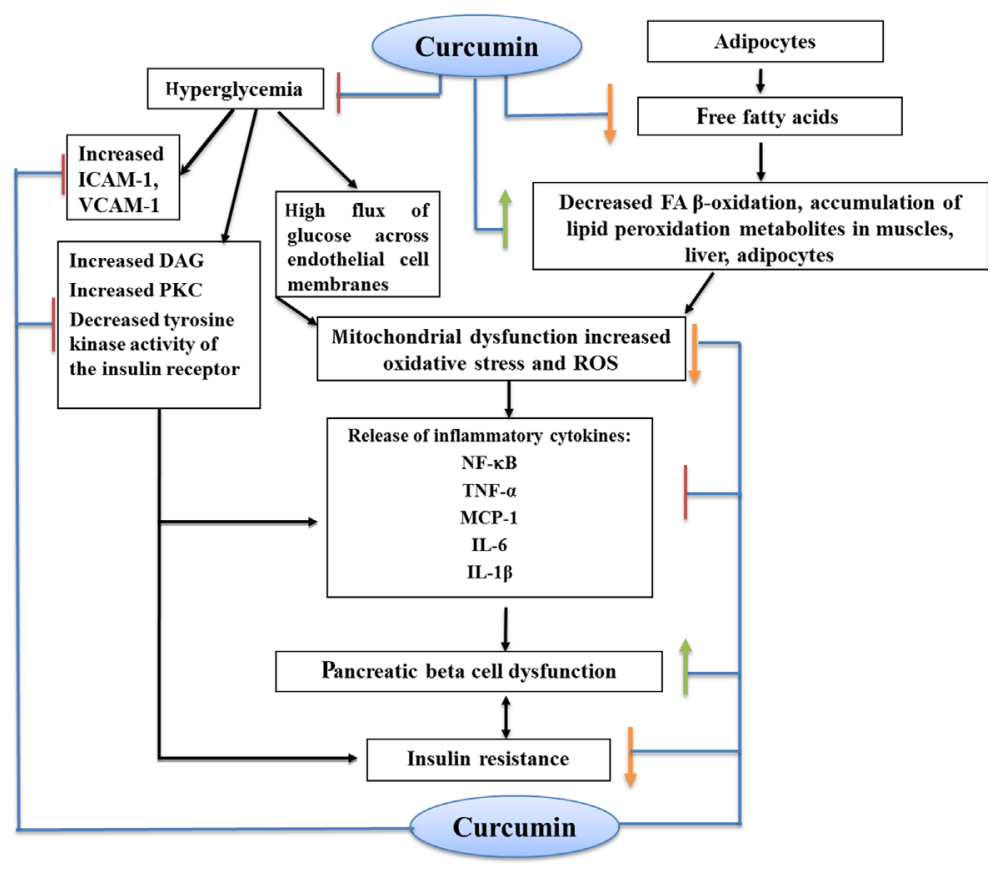

Figure 3. Antihyperglycemic and Anti-Insulin Resistance Effects of Curcumin

\begin{tabular}{|c|c|c|c|c|c|}
\hline patients & Dose, Duration & $\begin{array}{l}\text { Results In the End of the Study in } \\
\text { Treatment Group }\end{array}$ & Overall Conclusion & $\begin{array}{l}\text { Authors/Publica- } \\
\text { tion year }\end{array}$ & $\begin{array}{l}\text { Reference } \\
\text { Number }\end{array}$ \\
\hline $\begin{array}{l}\text { 100 Overweight/ } \\
\text { obese type } 2 \text { dia- } \\
\text { betic patients }\end{array}$ & $\begin{array}{l}\text { Curcuminoids ( } 300 \\
\text { mg/day) } 3 \text { months }\end{array}$ & $\begin{array}{c}\text { fasting blood glucose } \downarrow \text {, insulin } \\
\text { resistance index (HOMA-IR) } \downarrow \text {, serum } \\
\text { total FFAs } \downarrow \text {, serum triglycerides } \downarrow \text {, } \\
\text { LPL activity } \uparrow\end{array}$ & $\begin{array}{l}\text { These findings indicate a glucose- } \\
\text { lowering effect of Curcuminoids in } \\
\text { type } 2 \text { diabetes, which is partially } \\
\text { due to decrease in serum FFAs, } \\
\text { which may result from promoting } \\
\text { fatty acid oxidation and utilization }\end{array}$ & $\begin{array}{l}\text { Na LX and col- } \\
\text { leagues/ } 2012\end{array}$ & $(46)$ \\
\hline $\begin{array}{l}\text { subjects }(n=240) \\
\text { with criteria of } \\
\text { prediabetes }\end{array}$ & $\begin{array}{l}\text { six Curcumin } \\
\text { capsules per day } \\
\text { (Each capsule } \\
\text { has Curcuminoid } \\
\text { content of } 250 \mathrm{mg} \text { ) } \\
\text { 9months }\end{array}$ & $\begin{array}{c}\text { 16.4\% of subjects in the placebo group } \\
\text { were diagnosed with T2DM, whereas } \\
\text { none were diagnosed with T2DM } \\
\text { in the Curcumin-treated group the } \\
\text { Curcumin-treated group showed: } \\
\text { a better overall function of } \beta \text { cells } \\
\text { HOMA- } \beta \uparrow, C \text {-peptide } \downarrow, \text { HOMA-IR } \downarrow \text {, } \\
\text { Adiponectin } \uparrow\end{array}$ & $\begin{array}{l}\text { Curcumin intervention in a } \\
\text { pre-diabetic population signifi- } \\
\text { cantly lowered the number of pre } \\
\text { diabetic individuals who eventually } \\
\text { developed T2DM. In addition, the } \\
\text { Curcumin treatment appeared to } \\
\text { improve overall function of } \beta \text {-cells, } \\
\text { with very minor adverse effects. }\end{array}$ & $\begin{array}{l}\text { Chuengsamarn } \\
\text { Sand colleagues } \\
\qquad / 2012\end{array}$ & $(47)$ \\
\hline $\begin{array}{l}\text { Eleven healthy } \\
\text { subjects, aged } \\
21-38 \text { y with nor- } \\
\text { mal fasting blood } \\
\text { glucose }(100 \mathrm{mg} / \\
\text { dL) and total } \\
\text { cholesterol ( } 200 \\
\text { mg/dL) concentra- } \\
\text { tions }\end{array}$ & $\begin{array}{l}\text { a randomly as- } \\
\text { signed, crossover } \\
\text { design: } 6 \text { subjects } \\
3.0 \text { g cinnamon } \\
\text { 5subjects } 2.8 \text { g tur- } \\
\text { meric per day each } \\
\text { treatment } 4 \text {-wk }\end{array}$ & $\begin{array}{l}\text { no significant changes in fasting } \\
\text { plasma glucose or lipids in conjunc- } \\
\text { tion with the } 4 \text {-wk periods of each } \\
\text { treatment. }\end{array}$ & $\begin{array}{l}\text { Maybe turmeric supplementation in } \\
\text { healthy nondiabetic subjects did not } \\
\text { reflect blood glucose-lowering effect }\end{array}$ & $\begin{array}{l}\text { Tang } M \text { and col- } \\
\text { leagues/ } 2008\end{array}$ & (48) \\
\hline $\begin{array}{l}60 \text { subjects, } 20 \\
\text { years old and } \\
\text { above, who were } \\
\text { diagnosed mild to } \\
\text { moderate elevat- } \\
\text { ed ALT levels with } \\
\text { normal glucose } \\
\text { levels }(91.9 \pm 9.7)\end{array}$ & $\begin{array}{l}\text { fermented turmeric } \\
\text { powder } 3.0 \mathrm{~g} \text { per } \\
\text { day } 12 \text { weeks }\end{array}$ & $\begin{array}{l}\text { reduction in ALT,AST levels no signifi- } \\
\text { cant changes in blood glucose level }\end{array}$ & $\begin{array}{l}\text { FTP is effective and safe, gener- } \\
\text { ally well-tolerated without severe } \\
\text { Adverse events, in the treatment } \\
\text { of subjects with elevated ALT levels } \\
\text { over a } 12 \text { weeks period }\end{array}$ & $\begin{array}{l}\text { Kim SW and col- } \\
\text { leagues /2013 }\end{array}$ & (49) \\
\hline $\begin{array}{l}\text { Fourteen healthy } \\
\text { subjects in a cross- } \\
\text { over trial. }\end{array}$ & $\begin{array}{l}75 \text { g oral glucose } \\
\text { tolerance test } \\
\text { (OGTT) together } \\
\text { with capsules con- } \\
\text { taining a placebo or } \\
\text { C. longa }(6 \mathrm{~g})\end{array}$ & $\begin{array}{l}\text { no significant effect on the glucose } \\
\text { response The insulin AUCs were } \\
\text { significantly higher }\end{array}$ & $\begin{array}{l}\text { The ingestion of } 6 \mathrm{gC} \text {. longa } \\
\text { increased postprandial serum } \\
\text { insulin levels, but did not seem to } \\
\text { affect plasma glucose levels or GI, in } \\
\text { healthy subjects. The results indicate } \\
\text { that C. longa may have an effect on } \\
\text { insulin secretion }\end{array}$ & $\begin{array}{l}\text { Wickenberg J and } \\
\text { colleagues/2010 }\end{array}$ & $(47)$ \\
\hline
\end{tabular}

\footnotetext{
${ }^{\text {a }}$ HOMA-IR, insulin resistance index; OGTT,glucose tolerance test.
} 
Increases phosphorylation of AKT (PKB), insulin receptor and IRS-1. Decreases PTP1B and HOMA-IR. Increases HOMA and improves cell function.Stimulates insulin secretion from pancreatic tissues. Increase GLUT 4 and stimulates of glucose uptake.Reduces the oxidative stress and inflammatory state. Increases the adiponectin levels.Decreases HbA1c and blood glucosylation toward improving the insulin sensitivity and glucose control in skeletal muscle. Anti hyperglycemic and anti insulin resistance effects of curcumin are shown in Figure 3.

\section{Conclusions}

Curcumin can reduce blood glucose and HbAlc level by reduction in hepatic glucose production and glycogen synthesis and stimulation of glucose uptake by increasing GLUT4, GLUT2 and GLUT3 gene expressions, increasing activation of AMP kinase, promoting PPAR $\gamma$ ligandbinding activity, suppressing hyperglycemia-induced inflammatory state, stimulation of insulin secretion from pancreatic tissues, improvement in pancreatic cell function, Increasing phosphorylation of AKT (PKB), insulin receptor $\beta$ and reduction of insulin resistance. In human clinical trials conducted on diabetic and prediabetic patients, glucose lowering effect of turmeric and curcumin have been observed. However, no effect was seen in patients with normal baseline levels of blood sugar. More studies evaluating the effects of curcumin on hyperglycemic state and insulin resistance in related diseases such as diabetes are recommended.

\section{Authors' Contributions}

Study concept and design, analysis and interpretation of data, drafting of the manuscript and revision of the manuscript for important intellectual content: Zeinab Ghorbani, Azita Hekmatdoost, and Parvin Mirmiran.

\section{References}

1. Agrawal S, Chakrabarti A. Potential Nutraceutical Ingredients from Plant Origin. In: editor Handbook of Nutraceuticals editor. Pathak Y,:: CRC Press; 2010. pp. 30-1.

2. Kotwal GJ. A Versatile Nutraceutical and an Inhibitor of Complemen. In: Boca R editor. Kotwal GJ. Curcumin.. Nutraceuticals: CRC Press; 2010. pp. 217-20.

3. Gupta SC, Sung B, Kim JH, Prasad S, Li S, Aggarwal BB. Multitargeting by turmeric, the golden spice: From kitchen to clinic. Mol Nutr Food Res. 2013;57(9):1510-28.

4. Tilak JC, Banerjee M, Mohan H, Devasagayam TP. Antioxidant availability of turmeric in relation to its medicinal and culinary uses. Phytother Res. 2004;18(10):798-804.

5. Jurenka JS. Anti-inflammatory properties of curcumin, a major constituent of Curcuma longa: a review of preclinical and clinical research. Altern Med Rev. 2009;14(2):141-53.

6. Gupta SC, Kismali G, Aggarwal BB. Curcumin, a component of turmeric: from farm to pharmacy. Biofactors. 2013;39(1):2-13.

7. Sohrab G, Hosseinpour-Niazi S, Hejazi J, Yuzbashian E, Mirmiran P, Azizi F. Dietary polyphenols and metabolic syndrome among Iranian adults. Int J Food Sci Nutr. 2013;64(6):661-7.

8. Maradana MR, Thomas R, O'Sullivan BJ. Targeted delivery of curcumin for treating type 2 diabetes. Mol Nutr Food Res. 2013;57(9):1550-6.

9. Rahman I, Biswas SK. Regulation of Inflammation, Redox, and Glu- cocorticoid Signaling by Dietary Polyphenols. In: Surh YJ, Dong Z, Cadenas E, Packer L editors. . Boca Raton: CRC Press; 2009.

10. Grynkiewicz G, Slifirski P. Curcumin and curcuminoids in quest for medicinal status. Acta Biochim Pol. 2012;59(2):201-12.

11. Shishodia S, Sethi G, Aggarwal BB. Curcumin: getting back to the roots. Ann N YAcad Sci. 2005;1056:206-17.

12. Sahebkar A. Why it is necessary to translate curcumin into clinical practice for the prevention and treatment of metabolic syndrome? BioFactors. 2013;39(2):197-208.

13. Soetikno V, Suzuki K, Veeraveedu PT, Arumugam S, Lakshmanan $\mathrm{AP}$, Sone $\mathrm{H}$, et al. Molecular understanding of curcumin in diabetic nephropathy. Drug Discov Today. 2013;18(15-16):756-63.

14. Asghari G, Sheikholeslami S, Mirmiran P, Chary A, Hedayati M, Shafiee A, et al. Effect of pomegranate seed oil on serum TNF-alpha level in dyslipidemic patients. Int J Food Sci Nutr. 2012;63(3):368-71.

15. Jacob A, Wu R, Zhou M, Wang P. Mechanism of the Anti-inflammatory Effect of Curcumin: PPAR-gamma Activation. PPAR Res. 2007;2007:89369.

16. Panzhinskiy E, Hua Y, Lapchak PA, Topchiy E, Lehmann TE, Ren J, et al. Novel curcumin derivative CNB-001 mitigates obesity-associated insulin resistance. J Pharmacol Exp Ther. 2014;349(2):248-57.

17. Martyn JA, Kaneki M, Yasuhara S. Obesity-induced insulin resistance and hyperglycemia: etiologic factors and molecular mechanisms. Anesthesiology. 2008;109(1):137-48.

18. Paul S, Jellinger.. Metabolic consequences of hyperglycemia and insulin resistance. Clinical Cornerstone. 2007;8:S30-42.

19. Bahadoran Z, Mirmiran P, Azizi F. Potential efficacy of broccoli sprouts as a unique supplement for management of type 2 diabetes and its complications. J Med Food. 2013;16(5):375-82.

20. Hekmatdoost A, Mirmiran P, Hosseini-Esfahani F, Azizi F. Dietary fatty acid composition and metabolic syndrome in Tehranian adults. Nutrition. 2011;27(10):1002-7.

21. Shao W, Yu Z, Chiang Y, Yang Y, Chai T, Foltz W, et al. Curcumin prevents high fat diet induced insulin resistance and obesity via attenuating lipogenesis in liver and inflammatory pathway in adipocytes. PLoS One. 2012;7(1).

22. Bahadoran Z, Mirmiran P, Azizi F. Dietary polyphenols as potential nutraceuticals in management of diabetes: a review. J Diabetes Metab Disord. 2013;12(1):43.

23. Brownlee M. The pathobiology of diabetic complications: a unifying mechanism. Diabetes. 2005;54(6):1615-25.

24. Campos C. Chronic hyperglycemia and glucose toxicity: pathology and clinical sequelae. Postgrad Med. 2012;124(6):90-7.

25. Peeyush KT, Gireesh G, Jobin M, Paulose CS. Neuroprotective role of curcumin in the cerebellum of streptozotocin-induced diabetic rats. Life sciences. 2009;85(19-20):704-10.

26. Na LX, Zhang YL, Li Y, Liu LY, Li R, Kong T, et al. Curcumin improves insulin resistance in skeletal muscle of rats. Nutr Metab Cardiovasc Dis. [Research Support, Non-U.S. Gov't]. 2011 Jul;21(7):526-33.

27. El-Moselhy MA, Taye A, Sharkawi SS, El-Sisi SF, Ahmed AF. The antihyperglycemic effect of curcumin in high fat diet fed rats. Role of TNF-alpha and free fatty acids. Food Chem Toxicol. 2011;49(5):1129-40.

28. Arun N, Nalini N. Efficacy of turmeric on blood sugar and polyol pathway in diabetic albino rats. Plant Foods Hum Nutr. 2002;57(1):41-52.

29. Weisberg SP, Leibel R, Tortoriello DV. Dietary curcumin significantly improves obesity-associated inflammation and diabetes in mouse models of diabesity. Endocrinology. 2008;149(7):3549-58.

30. Seo KI, Choi MS, Jung UJ, Kim HJ, Yeo J, Jeon SM, et al. Effect of curcumin supplementation on blood glucose, plasma insulin, and glucose homeostasis related enzyme activities in diabetic $\mathrm{db} / \mathrm{db}$ mice. Mol Nutr Food Res. 2008;52(9):995-1004.

31. Kuroda M, Mimaki Y, Nishiyama T, Mae T, Kishida H, Tsukagawa $\mathrm{M}$, et al. Hypoglycemic effects of turmeric (Curcuma longa L. rhizomes) on genetically diabetic KK-Ay mice. Biol Pharm Bull. 2005;28(5):937-9.

32. Li Y, Zhang Y, Liu DB, Liu HY, Hou WG, Dong YS. Curcumin attenuates diabetic neuropathic pain by downregulating TNF-alpha in a rat model. Int J Med Sci. 2013;10(4):377-81.

33. Nishiyama T, Mae T, Kishida H, Tsukagawa M, Mimaki Y, Kuroda $\mathrm{M}$, et al. Curcuminoids and sesquiterpenoids in turmeric (Cur- 
cuma longa L.) suppress an increase in blood glucose level in type 2 diabetic KK-Ay mice. J Agric Food Chem. 2005;53(4):959-63.

34. Mohankumar S, McFarlane JR. An aqueous extract of Curcuma longa (turmeric) rhizomes stimulates insulin release and mimics insulin action on tissues involved in glucose homeostasis in vitro. Phytother Res. 2011;25(3):396-401.

35. Cheng TC, Lin CS, Hsu CC, Chen LJ, Cheng KC, Cheng JT. Activation of muscarinic M-1 cholinoceptors by curcumin to increase glucose uptake into skeletal muscle isolated from Wistar rats. Neurosci Lett. 2009;465(3):238-41.

36. Pan Y, Wang Y, Cai L, Cai Y, Hu J, Yu C, et al. Inhibition of high glucose-induced inflammatory response and macrophage infiltration by a novel curcumin derivative prevents renal injury in diabetic rats. Br J Pharmacol. 2012;166(3):1169-82.

37. Jang EM, Choi MS, Jung UJ, Kim MJ, Kim HJ, Jeon SM, et al. Beneficial effects of curcumin on hyperlipidemia and insulin resistance in high-fat-fed hamsters. Metabolism. 2008;57(11):1576-83.

38. Yu W, Wu J, Cai F, Xiang J, Zha W, Fan D, et al. Curcumin alleviates diabetic cardiomyopathy in experimental diabetic rats. PLoS One. 2012;7(12)

39. Sharma S, Kulkarni SK, Chopra K. Curcumin, the active principle of turmeric (Curcuma longa), ameliorates diabetic nephropathy in rats. Clin Exp Pharmacol Physiol. 2006;33(10):940-5.

40. Soetikno V, Sari FR, Veeraveedu PT, Thandavarayan RA, Harima M, Sukumaran V, et al. Curcumin ameliorates macrophage infiltration by inhibiting NF-kappaB activation and proinflammatory cytokines in streptozotocin induced-diabetic nephropathy. Nutr Metab (Lond). 2011;8(1):35.

41. Fujiwara H, Hosokawa M, Zhou X, Fujimoto S, Fukuda K, Toyoda $\mathrm{K}$, et al. Curcumin inhibits glucose production in isolated mice hepatocytes. Diabetes Res Clin Pract. 2008;80(2):185-91.
42. Kanitkar M, Gokhale K, Galande S, Bhonde RR. Novel role of curcumin in the prevention of cytokine-induced islet death in vitro and diabetogenesis in vivo. Br J Pharmacol. 2008;155(5):702-13.

43. Best L, Elliott AC, Brown PD. Curcumin induces electrical activity in rat pancreatic beta-cells by activating the volume-regulated anion channel. Biochem Pharmacol. 2007;73(11):1768-75.

44. Ceriello A, Falleti E, Motz E, Taboga C, Tonutti L, Ezsol Z, et al Hyperglycemia-induced circulating ICAM-1 increase in diabetes mellitus: the possible role of oxidative stress. Horm Metab Res. 1998;30(3):146-9.

45. Gustavsson C, Agardh CD, Zetterqvist AV, Nilsson J, Agardh E, Gomez MF. Vascular cellular adhesion molecule-1 (VCAM-1) expression in mice retinal vessels is affected by both hyperglycemia and hyperlipidemia. PLoS One. 2010;5(9).

46. Na LX, Li Y, Pan HZ, Zhou XL, Sun DJ, Meng M, et al. Curcuminoids exert glucose-lowering effect in type 2 diabetes by decreasing serum free fatty acids: a double-blind, placebo-controlled trial. Mol Nutr Food Res. [Research Support, Non-U.S. Gov't]. 2013 Sep;57(9):1569-77.

47. Chuengsamarn S, Rattanamongkolgul S, Luechapudiporn R, Phisalaphong C, Jirawatnotai S. Curcumin extract for prevention of type 2 diabetes. Diabetes Care. 2012 Nov;35(11):2121-7.

48. Tang M, Larson-Meyer DE, Liebman M. Effect of cinnamon and turmeric on urinary oxalate excretion, plasma lipids, and plasma glucose in healthy subjects. Am J Clin Nutr. 2008;87(5):1262-7.

49. Kim SW, Ha KC, Choi EK, Jung SY, Kim MG, Kwon DY, et al. The effectiveness of fermented turmeric powder in subjects with elevated alanine transaminase levels: a randomised controlled study. BMC Complement Altern Med. 2013;13:58. 